\title{
Encontros com Imagens, Pesquisa e Educação
}

O s textos deste Dossiê reúnem professores/as e pesquisadores/as ligados/as ao Laboratório Educação e Imagem do Programa de Pós-Graduação em Educação da Universidade Estadual do Rio de Janeiro (UERJ), Grupo de Pesquisa que toma a imagem como elemento importante e deflagrador do ensino e da pesquisa em escolas e comunidades. Os autores e autoras reconhecem que, além da diversidade e possibilidades das imagens nos processos educativos e de investigação, territórios visuais expandidos e, muitas vezes, entrecruzados com outras formas expressivas, são fontes geradoras de formação, conhecimento e questionamentos. Assim, a imagem não é apenas um registro ou testemunho de acontecimentos e formas de pensar e projetar mundos mas, também, e de forma inapelável, um elemento que faz circular desejos, afetos e sentidos, possibilitando narrativas que mostram como e porque imagens podem ser invisibilizadas pela cultura dominante.

Abraçando amplos e diferenciados territórios - o audiovisual, a fotografia, o vídeo, o cinema e as narrativas -, os/as autores/as conjugam e compartilham experiências investigativas em contextos variados incluindo escolas públicas da cidade do Rio de Janeiro, Vitória e Conacri, na África. Sempre se defrontando com questões do cotidiano, alguns trabalhos nos oferecem ricas discussões sobre temas problemáticos e problematizadores como a estetização da escola e a presença religiosa nesses ambientes, criando 'mundos culturais' que nomeiam, discriminam e diferenciam estudantes. A necessidade e destaque para formas distintas de diálogo é uma posição que pode ser apreendida dos textos deste Dossiê, chamando a atenção para as condições de intervenção nas relações de poder - para além da reflexão sobre elas - incluindo aquelas que dizem respeito a nossa própria existência e ao lugar no qual vivemos. 
A curiosidade por adentrarmos em territórios desconhecidos ganha força e vitalidade através dos olhares dos/as pesquisadores/as que não se limitam a discutir imagens prontas, mas se arriscam a produzi-las e/ou orientar estudantes nesta direção, protagonizando atuações que articulam criação e reflexão. Também estão sob a perspectiva de debate neste Dossiê, exposições montadas com trabalhos de alunos, acercando-se, assim, do evento público como incitador da investigação.

Coerentes com um desenrolar inventivo e agregador, conscientes das circunstâncias que constroem a pesquisa na contemporaneidade, os/as autores/as seguem caminhos metodológicos que respeitam os deslocamentos, as contradições e atravessamentos dos temas, questões e elementos expressivos participantes de seus trabalhos. Eles criam, para os leitores, vias e veias por onde passam, transitam e circulam, não apenas imagens, mas também falas e sons, marcando encontros intensamente produtivos entre pesquisa e educação.

Convidamos a todos para se integrarem nestas propostas, repensando e reinventando seus fazeres educativos, apostando na pesquisa como base do aprender-ensinar e intensificando seus sentidos sobre a experiência sensível como uma contribuição indispensável para informar-se, conhecer e refletir sobre os impactantes fenômenos socioculturais que nos atingem. Nós crescemos e aprofundamos nossas capacidades profissionais - de professores/as e pesquisadores/as - na medida em que somos capazes de nos deslocar, de sair de nós mesmos e de trabalhar com 'outros' e para 'outros', de escutar, falar e discutir com 'outros'. É esta a expectativa maior que motiva a publicação do presente Dossiê.

Raimundo Martins e Irene Tourinho

Junho de 2016 


\section{RAIMUNDO MARTINS}

raimundomartins2005@yahoo.es

Professor Titular da Faculdade de Artes Visuais da Universidade Federal de Goiás (FAV/UFG), é Pós-doutor em Arte e Cognição pela Universidade de Londres (Inglaterra) e em Arte e Cultura Visual pela Universidade de Barcelona (Espanha).

\section{IRENE TOURINHO}

irenetourinho@yahoo.es

É professora titular aposentada da Faculdade de Artes Visuais (FAV) e Professora Permanente do Programa de Pós-Graduação em Arte e Cultura Visual. É membro do Grupo de Pesquisa em Arte, Educação e Cultura (GEPAEC) da Universidade Federal de Santa Maria, do Grupo de Pesquisa em Cultura Visual e Educação, da Universidade Federal de Goiás e do Grupo de Pesquisa Transviaçoes, da Universidade de Brasília. É, também, membro da International Society for Education through Art (INSEA), da Rede Iberoamericana de Educação Artística (RIEA), da Associação Nacional de Pesquisa em Artes Plásticas (ANPAP), da Associação Nacional de Pesquisa e Pós-Graduação em Educação (ANPED) e da Federação de Arte Educadores do Brasil (FAEB). 